\title{
STRUKTUR KESEIMBANGAN DAN KESELARASAN DALAM KAIN TENUN GOTYA DI DESAADAT TENGANAN PEGRINGSINGAN
}

\author{
I Wayan Dedy Prayatna \\ Program Pascasarjana \\ Institut Seni Indonesia Denpasar \\ JI. Nusa Indah, Sumerta, Kota Denpasar, Bali 80235 \\ Email:dedyprayatna28@gmail.com \\ Hendra Santosa \\ Program Studi Seni Karawitan, \\ Institut Seni Indonesia Denpasar \\ Email:hendrasnts@gmail.com \\ Tjok Istri Ratna Cora \\ Program Studi Desain Mode, \\ Institut Seni Indonesia Denpasar \\ Email:ratnacora@gmail.com
}

\begin{abstract}
ABSTRAK
Kain tenun gotya merupakan salah satu kain tradisional di Desa Adat Tenganan Pegringsingan. Keunikan kain tenun gotya sebagai karya kain tenun yaitu dengan motif garis 2.1.2.1 berwarna hitam dengan arah horizontal dan vertikal dengan di dasari warna putih, sehingga kain gotya memiliki kualitas, nilai estetis. Diperlukan penyusunan prinsip desain untuk menghindari kemonotonan dan kekacau-balauan ke dalam sebuah karya seni. Prinsip keseimbangan dan keselarasan juga sangat diperhatikan dalam proses pembuatan kain tenun gotya mulai dari penyusunan warna dan motif sehingga menibulkan tekstur, hal tersebut bertujuan agar kain tenun gothia dapat enak dilihat, bersifat tenang, tidak berat sebelah. Tujuan dari penulisan ini adalah untuk menganalisa prinsip keseimbangan dan keselarasan dalam kain tenun gotya. Permasalahan yang dibahas adalah bagaimana struktur keseimbangan dan keselarasan dalam kain tenun Gotya? Metode yang digunakan adalah metode penelitian kualitatif dengan menggunakan teknik wawancara, observasi dan kepustakaan dalam pengmpulan data. Hasil menunjukan bahwa Keseimbangan yang diterapkan adalah keseimbangan formal, terlihat dari penerapan garis, warna, ukuran pada kain dengan kesamaan ukuran yang seimbang antar bagian yang lainnya. Keselarasan dicapai dengan mengadakan pengulangan warna dan garis pada motif kain tenun.
\end{abstract}

Kata kunci: Keseimbangan, Keselarasan, Kain Tenun Gotya.

\begin{abstract}
Gotya woven cloth is one of the traditional fabrics in the Tenganan Pegringsingan Traditional Village. The uniqueness of the gotya woven cloth as a woven fabric is the line motif 2.1.2.1 in black with horizontal and vertical directions with a white base, so that the gotya cloth has quality and aesthetic value. It is necessary to formulate design principles to avoid monotony and chaos in a work of art. The principle of balance and harmony is also very much considered in the process of making gotya woven fabrics, starting from the arrangement of colors and motifs so that they reveal the texture. This is supposed to make the gothya woven fabric can be seen, calm, and balanced. The purpose of this paper is to analyze the principles of balance and harmony in the gotya woven fabric. The problem discussed is how is the structure of balance and harmony in Gotya's woven fabric? The method used is a qualitative research method using interview, observation and literature study in collecting data. The results show that the balance that is applied is a formal balance, seen from the application of lines, colors, sizes on the fabric with the same size that is balanced among the parts. Harmony is achieved by repeating colors and lines on the woven fabric motif.
\end{abstract}

Keywords: Balance, Harmony, Gotya Woven Fabric. 


\section{A. Pengantar}

Indonesia kaya akan warisan budaya yang menjadikan salah satu kebanggaan bangsa. Salah satu dari warisan budaya yakni keragaman kain dan tenunan tradisional. Kain tenun Indonesia memiliki nilai kebudayaan yang sangat banyak dan luhur. Baik dari segi proses pembuatan, bentuk, fungsi dan makna. Menenun merupakan salah satu proses pembuatan kain dengan tehnik yang sederhana, dimana proses terjalinnya antara benang lungsi dan pakan secara bergantian berdasarkan motif yang diterapkan dengan bantuan alat tenun (Harmoko, 1995). Benang lungsi merupakan benang memanjang yang mengarah vertikal kain pada saat melakukan proses penenun, sedangkan benang pakan merupakan benang yang memanjang yang mengarah horizontal pada kain saat melakukan proses penenun (Hadisurya, dkk., 2011). Benang yang digunakan untuk membuat kain tenun biasanya terbuat dari serat kayu, kapas, sutra, dan lainnya. Pembuatan kain dengan teknik tenun ini umum dilakukan di Indonesia, dan memiliki jenis kain tenun yang khas sesuai kearifan lokal masyarakatnya.

Menenun merupakan salah satu budaya yang dijaga secara turun temurun oleh masyarakat Bali dan telah lama berkembang. Menenun merupakan akitvitas yang pada awalnya merupakan tradisi masyarakat untuk memenuhi kebutuhan di lingkungan desa tersebut baik dalam melaksanakan kegiatan keagamaan maupun kegiatan sehari hari. Selain menjadi tradisi, menenun berkembang menjadi industri kreatif untuk memenuhi kebutuhan ekonomi keluarga. Terdapat berbagai macam teknik tenun yang ada di Indonesia. Namun secara spesifik teknik tenun di Indonesia dapat dibedakan ke dalam 3 katagori jenis teknik tenun yaitu, tenun datar, tenun ikat, dan tenun songket. Ketiga jenis teknik tenun tersebut dapat ditemukan di kehidupan masyarakat Bali, dalam proses pembuatan kain tenun.

Desa Adat Tenganan Pegringsingan merupakan salah satu desa di Bali yang terkenal dengan pengrajin kain tenun di Indonesia bahkan sampai kemancanegara dan memiliki keanekaragaman hasil tenunannya. Adapun beberapa kain tenun yang dihasilkan oleh masyarakat Desa Adat Tenganan Pageringsingan adalah kain gedogan, kain Gringsing, kain idup panak, kain celagi manis, kain Gotya dan lain-lain. Dari beberapa kain tenun yang dihasilkan oleh masyarakat di Desa Adat Tenganan Pegringsingan kain tersebut digunakan untuk keperluan upacara adat, baik sebagai busana ataupun sebagai pelengkap upakara. Kain tenun tradisional di Desa Tenganan memiliki perbedaan mulai dari material, motif, fungsi hingga makna. Kain tenun Gotya merupakan salah satu kain tradisional di Desa Adat Tenganan Pegringsingan dan juga salah satu kain sakral yang digunakan setiap pelaksaan upacara di Desa Adat Tenganan baik digunakan untuk saput, anteng/selendang dan juga kalung, kain tenun gotya di ciptakan ratusan tahun oleh warga desa sejak dahulu. Masyarakat di Desa Adat Tenganan Pegringsingan menggunakan Kain gotya hanya dalam rentetan sebelum upacara puncak keagaman, dalam kehidupan sehari hari masyarakat tidak menggunakan kain tersebut dikarenakan kepercayaan terhadap symbol dan makna yang terdapat pada motif dan warna Kain gotya tersebut. Kain gotya dapat dikatakan sebagai kain bebali yang memiliki kualitas, nilai estetika dan makna khusus di dalamnya.

Kain gotya memiliki estetika khusus, dan keunikan tersendiri sebagai karya tekstil. keunikan dari kain gotya, Khas motif khusus yaitu motif garis berwarna hitam dengan arah horizontal dan vertikal dengan struktur 2.1.2.1 dengan di dasari warna putih. Proses yang sangat panjang mulai dari kapas dan benang yang ditenun menggunakan alat tenun tradisional tenganan yaitu Cag - cag hingga menjadi selembar kain. Kain gotya memiliki kualitas, nilai estetika dan makna khusus di dalam nya.

Menurut Djelantik, estetika adalah ilmu yang mempelajari tentang keindahan (A.A.M 2008). Sedangkan menurut (Mikke, 2011) estetika, adalah bagian dari filsafat yang membahas tentang karya seni dan keindahan serta pandangan atau pemikiran pengamat yang melihatnya. Dilihat beberapa pernyataan mengenai estetika, dapat disimpulkan bahwa, estetika merupakan perasaaan yang dimiliki oleh setiap individu pengamat dalam mengapresiasi keindahan dalam suatu karya seni yang dapat dilihat dan dirasakan melalui inderanya masing masing. Demikian juga dalam mengapresisasi sebuah karya tenun yang dapat dinikmati secara visual ataupun perasaan.

Keindahan sebuah karya tekstil bukan hanya tercermin dari bahan atau material yang digunakan. Kecermatan dalam penyusunan unsur-unsur rupa pembentuknya perlu diperhatikan. Karya seni tentu memiliki nilai estetika yang di dalamnya mengandung susunan atau struktur yang meliputi seluruh bagian dari karya tekstil tersebut dan fungsi dari masing masing bagiannya tersebut. Penyusunan setiap elemen dalam desain tenun gotya tentu tidak serta merta terjadi begitu saja. Penyusunan setiap unsur 


\section{GEEAR Jumal sai isulya}

seperti garis, bidang, warna, dan tekstur, telah mempertimbangkan pengorga-nisasian setiap unsurunsurnya untuk menciptakan desain yang utuh. Dalam membuat suatu karya seni perlu memperhatikan dan mempertimbangkan penerapan unsur-unsur rupa dalam mewujudkannya agar terhindar dari kemonotonan dan kekacaubalauan. Menurut Ebdi (2010), dalam menciptakan karya seni dapat dikatakan indah setidaknya memiliki tujuh prinsip dasar seni dan desain. Tujuh prinsip tersebut meliputi: keselarasan/ ritme/irama, kesatuan (unity), daya tarik/pusat perhatian, keseimbangan, proporsi/ perbandingan, kesederhanaan, dan kejelasan. Tujuh dasar prinsip desain akan memiliki perannya masing-masing dalam menciptakan kesinambungan unsur-unsur desain. Dalam menciptakan karya seni penerapaan prinsip keseimbangan dalam unsur karya seni dapat mempengaruhi karakter dari desain karya seni (Anggara, 2019).

Prinsip keseimbangan sangat diperhatikan dalam proses pembuatan kain tenun gotya. Keseimbangan dapat di lihat dalam kain tenun gotya mulai dari penyusunan warna, penyusunan motif, penggunaan bahan sehingga terbentuk nya suatu tekstur. penerapan prinsip keseimbangan dalam kain tenun gotya bertujuan agar kain tenun gotya dapat enak dilihat, bersifat tenang, tidak berat sebelah. Keseimbangan merupakan sesuatu yang saling berhadapan dan dapat menimbulkan kesan seimbang yang dapat dilihat atau dirasakan secara visual maupun perasaan. Ada dua macam keseimbangan, keseimbangan formal dan keseimbangan informal (Rianta 2019; Sony, 2007). Adanya keseimbangan pada kain renun gotya membuat kain tenun terlihat memiliki keselarasan. Keselarasan memiliki kesamaan dengan irama. Irama merupakan pengulangan satu atau beberapa unsur yang teratur dan terus menerus (Ebdi, 2010). Keselarasan menjadi hal yang sangat penting kaitannya dalam menciptakan karya desain tekstil. Prinsip keselarasan sangat diperhatikan dalam proses pembuatan kain tenun gotya. Keselarasan dapat dilihat di dalam kain tenun gotya mulai dari penyusunan warna dan penyusunan motif.

Berdasarkan uraian di atas, maka muncul permasalahan yaitu, Bagiamana struktur keseimbangan dan keselarasan warna, motif dan tekstur dalam kain tenun gotya? Setiap karya seni tenun memiliki struktur yang mempengaruhi keindahaan karya seni seperti keseimbangan dan keselarasan yang terdapat pada karya tersebut. Maka dari itu, pada artikel ini fokus kajian adalah struktur keseimbangan dan keselarasan yang diaplikasikan pada unur-unsur karya kain tenun gotya di Desa Adat Tenganan Pegringsingan.

Materi yang dikaji dalam tulisan ini ialah struktur keseimbangan dan keselarasan pada unsur garis, warna dan motif yang terdapat pada kain tenun gotya di Desa Adat Tenganan Pegringsingan

Metode yang digunakan adalah metode deskriptif dengan menguraikan struktur keseimbangan dan keselarasan dari kain tenun gotya. Adapun pendekatan penelitian ini mengikuti langkah-langkah kerja penelitian kualitatif, karena sifat data yang dikumpulkan adalah data kualitatif.

sumber data yang digunakan dalam penelitian ini yakni sumber data primer dan data sekunder. (Sugiyono 2012) Data primer dapat dilakukan dengan tehnik wawancara (Rohidi 2011), dan observasi. Wawancara di lakukan kepada dua narasumber. Pertama I Nyoman Sadra informasi yang didapatkan berupa sejarah keberadaan, fungsi dan makna dari kain tenun gotya. Kedua Ni Luh Widiartini, informasi yang di dapat berupa proses dan tehnik dari pembuatan kain tenun gotya.

Observasi dilakukan di Desa Tenganan Pegringsingan, dan melakukan pencatatan informasi mengenai proses, tehnik dalam pembuatan kain tenun gotya yang berkaitan dengan pengorganisasian struktur keseimbangan dan keselarasan dari kain tenun gotya.

Sumber data sekunder dapat dilakukan dengan tehnik dokumentasi dengan cara mencari di literatur, dokumen, atau catatan yang berkaitan dengan objek yang akan diteliti. Metode kepustakaan merupakan suatu tehnik pengumpulan data yang dilakukan dengan cara mencari hasil-hasil literature hasil penelitian mengenai objek tersebut, (Lubis 2007). Metode ini dilakukan dengan cara mencari data literatur pada buku yang berkaitan obek penelitian dan buku mengenai teori-teori yang akan digunakan dalam membedah penelitian dan artikel yang digunakan sebagai data pendukung dalam membedah objek penelitian.

\section{B. Pembahasan}

Desa Adat Tenganan Pegringsingan merupakan salah satu desa di Bali yang terkenal dengan pengrajin kain tenun di Indonesia bahkan sampai kemancanegara dan memiliki keanekaragaman hasil tenunannya. Adapun beberapa kain tenun yang dihasilkan oleh masyarakat Desa Adat Tenganan Pageringsingan adalah kain gedogan, 
kain gringsing, kain idup panak, kain celagi manis, kain gotya dan lain-lain. Setiap kain tradisional di Desa Tenganan memiliki perbedaan mulai dari material, motif, fungsi hingga makna. Kain tenun gotya merupakan salah satu kain tradisional di Desa Adat Tenganan Pegringsingan.

Bapak Nyoman Sadra dalam wawancara pada 15 April 2019 menjelaskan bahwa:

Kain Tenun gotya tergolong Kain Bebali (Kain Bali) sebagai kain sakral yang sangat sederhana baik dalam penampilan maupun pembuatannya. dan juga salah satu kain sakral yang digunakan setiap pelaksaan upacara di Desa Adat Tenganan oleh Teruna, Dehe dan Desa digunakan untuk saput, anteng/ selendang dan juga kalung, dalam proses penggunaannya kain gotya harus menyatukan dua lembar kain gotya. kain tenun gotya di ciptakan ratusan tahun oleh warga desa sejak dahulu, namun, hingga saat ini tidak ada catatan tertulis secara resmi mengenai asal mula tenun gotya di desa Tenganan Pegringsingan,

Kain bebali memiliki warna yang polos, memiliki motif garis, ataupun kotak-kotak dan beraneka ragam warna, kain bebali sering digunakan untuk keperluan upacara agama (Bandem 1996). Kain gotya memiliki estetika khusus, dan keunikan tersendiri sebagai karya tekstil. keunikan dari kain gotya, yaitu khas motif khusus garis dengan struktur 2.1.2.1 berwarna hitam dengan arah horizontal dan vertikal juga terdapat sebuah motif berbentuk persegi empat dan persegi panjang yang berwarna putih,

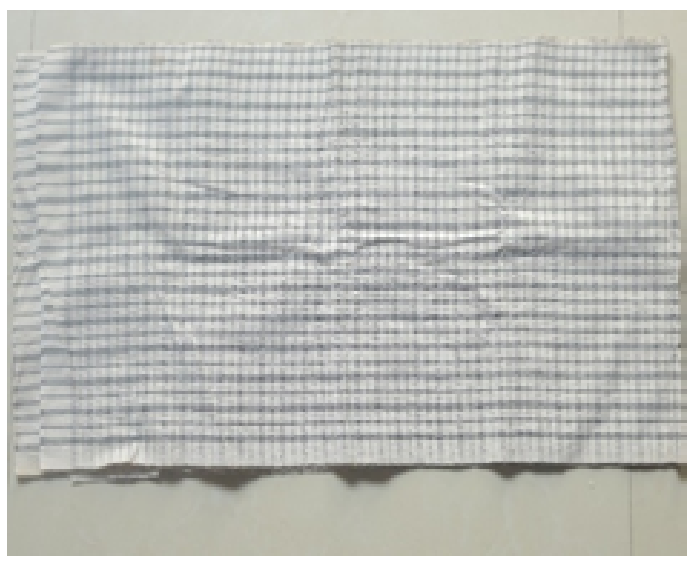

Gambar 1: Kain Tenun Gotya

(Sumber: Dokumentasi Dedy Prayatna, 2019)
Proses pembuatan yang sangat panjang mulai dari kapas dan benang yang ditenun menggunakan alat tenun tradisional tenganan yaitu cag - cag. Cag cag merupakan alat tenun tradisional DesaAdat Tenganan. Cag-cag adalah dua batang kayu yang berdiri dan diberi lubang untuk menaruh kayu yang akan digunakan untuk menggulung benang yang akan ditenun.

Salah satu ciri khas alat tersebut adalah bahwa dalam proses pekerjaannya, penenun memanfaatkan bagian pinggangnya untuk mengatur ketegangan dalam rentangan benang lungsi. Por, semacam busur, disangkutkan pada pinggang penenun sebagai penahan rentangan benang lungsi. Adapun hasil tenunan yang dihasilkan oleh alat tenun cag cag biasanya berbentuk tabung. Setelah dipotong mengikuti alur pakan, kain tersebut akan menjadi persegi panjang berukuran lebar $30-100 \mathrm{~cm}$, panjang $125-200 \mathrm{~cm}$.

Ibu Ni Kembang dalam wawancara pada 3 April 2019 menjelaskan bahwa:

Cag cag di lengkapi dengan sisir untuk mengendalikan benang lungsi dan merapatkan hasil tenunan, sehingga hasil motif dari tenun dengan alat cag cag bisa saja tidak teratur atau bergelombang (medon tebu).

Gedogan merupakan salah satu alat menenun tradisional yang di miliki Desa Adat Tenganan Pegringsingan. Terdapat dua macam alat tenun gedogan yang dapat dibedakan dari penempatan benang lungsi yaitu gedogan berlungsi sinambung dan gedogan berlungsit tak lanjut. Gedogan berlungsi sinambung merupakan alat tenun yang sering di pakai untuk menenun di Desa Adat Tenganan .pada alat tenun ini benang lungsi meliliti batang apit dan bertemu sambung dengan benang lungsi pada batang totogan, sehingga melingkar secara utuh (Harmoko 1995) Dengan adanya alat tenun ini berarti alat tenunya dapat dipindah pindah. Dalam proses menenun menggunakan alat tradisional membutuhkan keahlian khusus karena kerumitan dalam proses pemasangan benang, sehingga memerlukan waktu yang lama dalam proses menenun

Ibu Ni Luh Kembang dalam wawancara tanggal 14 juni 2019 menjelaskan bahwa:

Kain tenun gotya dibuat dengan benang bali berupa kapas yang digiling mengecil sehingga menjadi sebuah benang panjang dan di direndam dengan bubur nasi. Alat tenun yang digunakan berupa cag cag dengan tehnik meserat 


\section{GE[AR Jumal Sori Bublya}

Teknik dalam pembuatan kain yang dibuat dengan tehnik yang sederhana, proses terjalinnya antara benang lungsi dan pakan secara bergantian berdasarkan motif yang di terapkan dengan bantuan alat tenun. Dengan kata lain, terjalinnya antara benang lungsi dan pakan secara bergantian. Benang lungsi merupakan benang memanjang yang mengarah vertikal kain pada saat melakukan proses penenun, sedangkan benang pakan merupakan benang yang memanjang yang mengarah horizontal pada kain saat melakukan proses penenun. Masyarakat di Desa Tenganan menggunakan kain gotya hanya pada upacara keagamaan saja, dan tidak untuk digunakan dalam aktivitas sehari-hari. Hal ini terkait dengan kepercayaan terhadap symbol dan makna yang terdapat pada motif dan warna kain gotya tersebut. Kain gotya memiliki kualitas, nilai estetika dan makna khusus di dalamnya.

Melalui beberapa tahapan dalam proses pembuatan kain tenun gotya yang telah dijelaskan di atas, dapat dilihat bahwa setiap unsur yang membentuk tenun gotya sangat meperhatikan penyusunan unsur-unsurnya untuk menciptakan suatu karya tenun yang memiliki nilai estetis. K. Kuypers memiliki pemikiran mengenai estetika yakni dimana sesuatu yang ada kaitannya dengan pengamatan. Kuypers juga membagi estetika menjadi dua bagian yakni estetika isi dan estetika bentuk. Estetika bentuk merupakan nilai-nilai yang melekat pada wujud visual karya seni yang dapat diamati oleh panca indera sang pengamat (Kuypers, 1977). Djelantik menyebutkan bahwa terdapat tiga unsur estetika yaitu wujud atau rupa, bobot atau isi dan penampilan. Djelantik menambahkan bahwa wujud mengacu pada sesuatu yang nyata atau dapat dilihat maupun sesuatu yang bersifat abstrak atau hanya bisa dibayangkan (Djelantik, 2008). Berdasarkan dua pendapat tersebut, maka dalam estetika bentuk atau wujud, merupakan nilai-nilai keindahan yang melekat pada karya seni, nampak secara kongkrit, dapat dibayangkan melalui pengamatan panca indera. Di dalam wujud karya seni, terdapat penataan atau pengorganisasian beberapa unsur dalam struktur karya seni.

Keindahan sebuah karya tekstil bukan hanya tercermin dari bahan atau material yang digunakan. Kecermatan dalam penyusunan unsur-unsur rupa pembentuknya perlu diperhatikan. Karya seni tentu memiliki nilai estetika yang di dalamnya mengandung susunan atau struktur yang meliputi seluruh bagian dari karya tekstil tersebut dan fungsi dari masingmasing bagiannya tersebut.
Menurut Ebdi (2010), karya seni rupa atau desain setidaknya memiliiki tujuh prinsip seni dan desain di dalam karya seni yang diciptakannya tersebut. Tujuh prinsip dasar seni dan desain itu meliputi, antara lain keselarasan (ritme atau irama), kesatuan (unity), dominasi (daya tarik/ pusat perhatian), keseimbangan, keselarasan (proporsi/ perbandingan), kesederhanaan, dan kejelasan. Tujuh dasar prinsip desain akan memiliki perannya masingmasing dalam menciptakan kesinambungan unsurunsur desain.

Unsur desain merupakan sesuatu yang digunakan untuk menciptakan suatu karya seni sehingga pengamat dapat memahami karya tersebut dengan jelas. Maksud unsur disini adalah unsur-unsur yang dapat dilihat atau sering disebut dengan unsur nyata. Unsur-unsur desain ini terdiri atas garis, arah, bentuk, tekstur, ukuran, value, dan warna. Melalui unsur visual inilah seorang perancang dapat mewujudkan rancangannya. Adanya 7 unsur ini menjadi sebuah kesamaan/keseimbangan yang dapat membentuk keindahan secara visual dari suatu karya seni (Baruna, 2019).

\section{Keseimbangan}

Keseimbangan merupakan keadaan yang saling berhadapan dan dapat menimbulkan kesan seimbang yang dapat dilihat atau dirasakan secara visual. atau intensitas kekaryaan. Bobot visual ditentukan oleh semua unsur dipertimbangkan dan memerhatikan keseimbangan (Novitasari, 2018) Ada dua macam keseimbangan, keseimbangan formal dan keseimbangan informal (Sony, 2007).

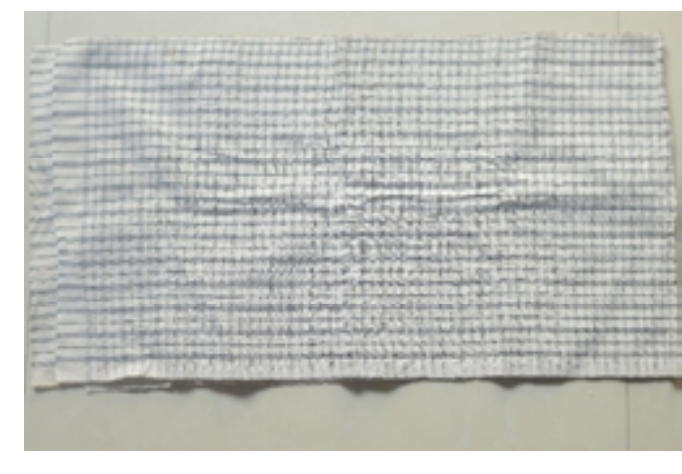

Gambar 2: Kain tenun Gothia

(Sumber: Dokumentasi Dedy Prayatna, 2019)

Keseimbangan formal merupakan keseimbangan dalam dua bagian berlawanan dari satu poros. Keseimbangan formal biasanya simetris. la dicapai dengan menyusun unsur unsur sejenis dan memiliki identiitas visual pada jarak yang sama 
terhadap suatu titik pusat. Keseimbangan simetris merupakan keseimbangan kedua bagian antara sebelah kiri dan sebelah kanan memiliki kesama semua unsurnya (Ebdi, 2010). Sedangkan keseimbangan informal merupakan keseimbangan yang menyebelah dari semua susunan unsur yang menggunakan prinsip ketidaksamaan atau kontras. Keseimbangan informal biasanya asimetris (Sony, 2007). Konsep dari keseimbangan dapat dilihat seperti berat dengan anak timbangan. Keseimbangan informal lebih terlihat rumit, namun lebih menarik para penikmat karena memiliki kesan dinamika yang memberi variasi yang lebih banyak. Keseimbangan Informal memiliki keunikan yang didasarkan atas perhitungan bobot visual dari unsur-unsur yang ditampilkan dalam karya seni. Di samping itu juga harus mempertimbangkan semua karakter pada masing-masing unsur yang terdapat dalam karya seni tersebut (Baruna, 2019).

Berdasarkan pernyataan di atas, maka prinsip keseimbangan yang diaplikasikan pada kain tenun gotya adalah jenis keseimbangan formal. Dalam bentuk rautannya karya ini, penerapan keseimbangan formal terlihat dari garis, ukuran, warna, dan tekstur. Berikut merupakan analisis prinsip keseimbangan pada unsur garis, motif, warna dan tekstur dalam karya kain tenun Gotya

\section{Garis}

Menurut Mikke Susanto, garis mempunyai tiga pengertian dan sama besar. Garis memiliki ukuran yang memanjang dan punya arah, bisa panjang, pendek, halus, tebal, berombak, melengkung, lurus, dan lain-lain (Mikke, 2011) Garis merupakan hasil goresan nyata yang disebut garis nyata. Garis juga merupakan batas suatu benda, batas sudut ruang, batas warna, rangkaian massa yang disebut garis semu/maya (Ebdi, 2010). Penerapan garis dengan keseimbangan formal pada karya kain tenun gotya diperoleh melalui kesamaan jarak, jumlah dan ukuran garis yang terlihat pada motif kain. Terdapat dua kelompok garis yang terlihat sebagai motif kain tenun. Pertama, Garis searah horizontal yang tercipta dari bat memiliki jarak yang teratur, ukuran yang sama dan jumlah motif 2.1.2.1 pada setiap garisnya. Kedua, garis searah vertikal yang tercipta dari benang lungsi memiliki jarak yang teratur dengan ukuran garis yang sama pula dan memiliki jumlah garis 2.1.2.1 pada setiap garisnya. Meskipun terdapat garis dua kelompok garis dengan arah yang berbeda, namun kesimbangan formal tetap tercapai memalui dimensi garis, dimana jumlah dan ukuran garis searah hori- zontal diseimbangkan dengan garis searah vertikal. Hal ini menimbulkan kesan simetris dan memberi rasa seimbang.

\section{Motif}

Motif merupakan gambaran ataupun corak yang terdapat pada kain sehingga membuat tampilan pada kain tersebut lebih menarik (Hadisurya, 2011). Motif berarti corak/pola (Nugraha, 2013). Motif merupakan desain yang dibuat dari bagian-bagian unsur dan elemen dalam pembentukan karya seni. atau elemen-elemen yang terkadang begitu kuat dipengaruhi oleh bentuk-bentuk stilasi alam benda, dengan gaya dan ciri khas tersendiri (Suhersono, 2011). Kain Gotya memiliki estetika khusus, khas motif khusus yaitu motif persegi empat dan persegi panjang dengan ukuran $1 \mathrm{~cm} \times 1 \mathrm{~cm}$ untuk persegi empat dan $1 \mathrm{~cm} \times 0,5 \mathrm{~cm}$ untuk persegi panjang. Motif persegi empat dan persegi panjang timbul akibat penggabungan antara garis berwarna hitam dengan arah horizontal dan vertikal dengan struktur 2.1.2.1 dengan di dasari warna putih. Seperti yang terlihat pada kain tenun gotya, keseimbangan formal tetap dapat diperoleh dengan mengadakan pengulangan kesamaan bentuk dan penempatan bidang di kanan dan kirinya, kedua sisi memilki berat yang seimbang. Pada dasarnya desain yang memiliki keseimbangn simetris relatif mudah ditangkap mata sehingga memiliki tendensi memberi rasa seimbang.

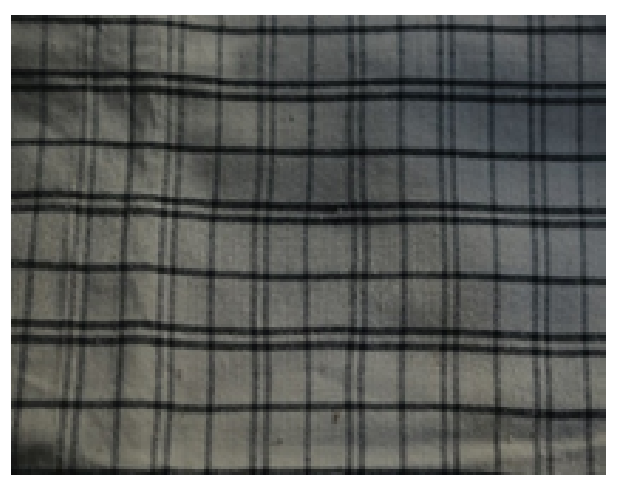

Gambar 3: Kain Gotya dengan motif Struktur garis 2.1.2.1

(Sumber: Dokumentasi Dedy Prayatna, 2019)

\section{Warna}

Warna merupakan salah satu unsur utama dalam karya seni (Sony 2007) Warna sangat berperan penting atau kental dengan kehidupan sehari-hari manusia. Hal tersebut dapat diperhatikan di sekeliling kita dari berbagai benda atau peralatan yang sering digunakan dalam kehidupan sehari hari. Warna 


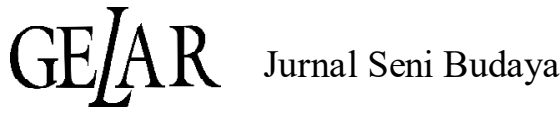

memiliki peranan yang sangat penting yaitu: warna sebagai warna, warna sebagai simbol alam, warna sebagai lambang, dan warna sebagai ekspresi (Sony, 2007). Warna sebagai lambang atau symbol. Dimana warna merupakan dapat melambangkan sesuatu tradisi atau pola umum. Kehadiran warna juga memberikan tanda tertentu yang sudah menjadikan kesepakatan umum misalkan tanda merah, kuning, hijau lampu jalan (Sony, 2007).

Setiap karya seni setidaknya harus memiliki keseimbangan di dalam semua unsur unsurnya. Warna merupakan salah satu unsur desain yang paling utama dalam suatu karya seni. Karena dengan adanya unsur warna, suatu benda dapat dilihat keindahannya. Dimana warna dapat memperlihatkan sifat, kepribadian,dan kebudayaan yang berbeda-beda (Zaman, 2011). Warna ditimbul karena adanya pantulan cahaya yang bersumber dari cahaya matahari atau sumber cahaya lainya. Kemudian cahaya tersebut memantul ke suatu objek (Darmaprawira, 2002). Terdapat dua warna pada kain tenun gotya yaitu warna putih pada motif persegi empat dan warna hitam pada garis vertikal dan horizontal. Seperti yang terlihat pada kain tenun gotya, keseimbangan formal tetap dapat diperoleh dengan mengadakan pengulangan warna yang sama dalam susunan sehingga memiliki tendensi memberi rasa seimbang.

\section{Tekstur}

Tekstur dapat dikelompokkan menjadi tekstur nyata, tekstur kasar semu dan tekstur halus. Tekstur kasar nyata dapat dirasakan dalam tekstur asli objek tersebut ataupun dengan melakukan beberapa hal terhadapt objek tersebut seperti memotong, merobek, melubangi, atau menambahkan perhiasan pada objek tersebut (Ebdi, 2010). Kain tenun gotya memiliki tekstur nyata teraba dengan tekstur yang bergelombang. Tesktur yang timbul pada saat penenunan kain hanyalah kombinasi tekstur kasar dengan kasa yang timbul akibat dari proses menenun dengan tehnik megedog dan penggunaan bahan. Dimana hasil dari menenun yang menggunakan tehnik megedong akan memiliki hasil yang bergelombang beda dengan menggunakan Alat Tenun Bukan Mesin (ATBM). sehingga perpaduan tekstur yang sejenis menghasilkan keseimbangan formal yang bersifat tenang tetapi tidak menampakkan pandangan yang menjemukan.

\section{Keselarasan}

Keselarasan sama dengan irama. Irama merupakan pengulangan satu dan beberapa unsur yang teratur dan terus menerus atau gerak yang mengalir ajeg. Ajeg yang dimaksud dalam hal ini bisa keajegan dalam kesamaan- kesamaan unsur, bisa keajegan dalam perubahan-perubahan unsur, atau bisa keajegan dalam kekontrasan, yang didesain secara terus menerus (Ebdi, 2010). Irama penataan ragam hias tenun gotya ditampilkan secara berulang-ulang secara teratur. Pengaturan disini dimaksudkan motifmotif yang sama disusun secara berulang-ulang tetapi tidak monoton sehingga secara keseluruhan tampak adanya irama. Irama dapat ditampilkan melalui pengaturan bentuk motif hias seperti: besar, kecil, tinggi, rendah, panjang, pendek, dan juga dalam pengaturan warna yang berbeda-beda secara berulangulang (Pendidikan, Rupa, and Keluarga 2013). Pada tenun gotya keselarasan terlihat dari unsur garis dan warna. Berikut merupakan analisis prinsip keselarasan pada unsur garis dan warna dalam karya kain tenun gotya

\section{Garis}

Garis yang terdapat pada motif kain tenun gotya adalah garis berwarna hitam searah horizontal dan garis searah vertikal. Perulangan dilakukan pada kedua garis, baik garis vertikal maupun garis horisontal untuk menghasilkan keselarasan melalui irama. Hal ini terlihat pada pengulangan motif garis 2.1.2.1.2.1 yang menerapkan jenis irama repetisi. Sanyoto menjelaskan, repetisi merupakan hubungan pengulangan dengan kesamaan ekstrem pada setiap unsur atau elemen pada pembentukan karya seni (Ebdi, 2010). Hal ini terlihat pada ukuran, arah, dan jarak dari garis vertical dan horizontal yang memiliki kesamaan dan pengulangan yang ajeg. Kesan yang ditimbulkan pada motif perulangan repetisi adalah statis, monoton, kaku sehingga berkesan menjemukan (Bali, 2014).

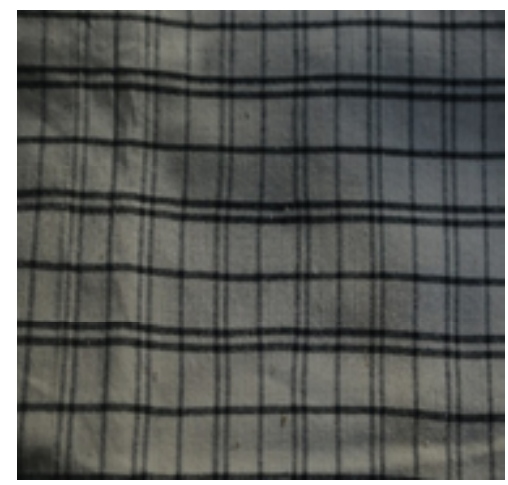

Gambar 4: Kain Gotya dengan pengulangan motif garis 2.1.2.1

(Sumber: Dokumentasi Dedy Prayatna, 2019) 


\section{Warna}

Warna sangat diperlukan pada setiap karya seni. Begitu pula pada sebuah kain tenun, penikmat karya akan merasa nyaman dengan tampilan warna yang selaras. Keselarasan warna dapat diperoleh dengan memperhatikan irama. Irama yang dimaksud kedalam hal ini adalah gerak warna dari satu warna ke warna lainnya. Warna-warna ini kemudian dilakukan pengulangan warna sehingga dapat menghasilkan kesan yang dinamis. Pada karya kain tenun gotya terdapat pengulangan warna hitam pada motif garis dan pengulangan warna putih pada dasar warna dari setiap motif dan warna pada karya kain tenun gotya.

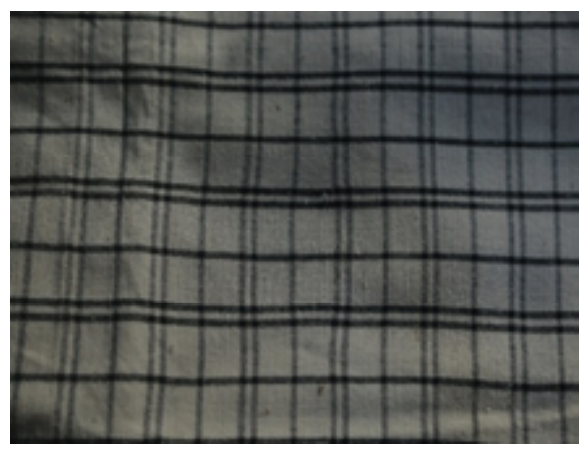

Gambar 5: Kain Gotya dengan pengulangan warna pada garis dan motif

(Sumber: Dokumentasi Dedy Prayatna, 2019)

\section{Kesimpulan}

Kain tenun gotya merupakan salah satu kain tradisional di DesaAdat Tenganan Pegringsingan. Kain gotya memiliki keunikan tersendiri sebagai karya tekstil. Dengan khas motif khusus yaitu garis 2.1.2.1 berwarna hitam dengan arah horizontal dan vertikal dengan di dasari warna putih namun juga memiliki nilai estetis. Ini terlihat dari penerapan unsur-unsur desain yang disusun atau diorganisir dengan baik menggunakan pedoman prinsip desain. Dari beberapa prinsip desain yang diterapkan, keseimbangan dan keselarasan menjadi pertimbangan yang cukup penting (Novitasari, 2018) dalam proses menciptakan karya kain tenun gotya. Adapun keseimbangan yang diterapkan adalah keseimbangan formal, terlihat pada penerapan garis, warna, Motif dan tekstur pada kain dengan kesamaan ukuran yang seimbang antar bagian yang berhadapan. Keselarasan dicapai dengan mengadakan pengulangan (irama) unsur warna dan garis pada motif kain tenun. Sedangkan pada unsur warna, keselarasan dicapai dengan mengkombinasikan warna putih dan hitam dilakukan secara perulangan perulangan

\section{KEPUSTAKAAN}

A.A.M, Djelantik. 2008. Estetika Sebuah Pengantar. Jakarta: Masyarakat Seni Pertunjukan Indonesia (MSPI).

Anggara. Hendra Santosa, A.A. Gde Bagus Udayana, I Gede Adi Sudi. 2019. "Character Education And Moral Value In 2d Animation Film Entitled 'Pendeta Bangau."' Capture: Jurnal Seni Media Rekam 10(2): 57-70. https:// jurnal.isi-ska.ac.id/index.php/capture/article/ view/2449.

Bali, C V Tarum. 2014. "Kajian Warna Dan Motif Kain Tenun Upcycle Pada Produk."

Bandem, I Made. 1996. Wastra Bali, Makna Simbolis Kain Bali. Denpasar: Hartanto Art Books.

Baruna Ariesta, I Gusti Bagus Bayu, and Nyoman Ayu Permata Dewi. 2019. "Kajian Keseimbangan Pada Pakaian Adat Matruna Nyoman Dan Madaha Desa Tenganan Pegringsingan." Jurnal Da Moda 1(1): 21-28.

Darmaprawira, Sulasmi. 2002. Warna/ : Teori Dan Penggunaanya. Jakarta: ITB.

Ebdi, Sanyoto Sadjiman. 2010. Nirmana ElemenElemen Seni Dan Desain. Yogyakarta: Jalasutra.

Hadisurya, Irma, Pambudy.Ninuk Mardina, Herman Jusuf .2011. Kamus Mode Indonesia. Jakarta: PT. Gramedia Pustaka Utama.

Harmoko, H. 1995. INDONESIA INDAH Tenunan Indonesia. Jakarta: Perum Percetakan Negara Republik Indonesia.

Kuypers, K. 1977. Encyclopedie van de Filosofie. Amsterdam: Elsevier.

Lubis, J. Sarwono \& H. 2007. Metode Riset Untuk Desain Komunikasi Visual. Yogyakarta: ANDI.

Maruta, Gautama; Hendra Santosa; I Wayan Swandi; Nyoman. 2019. "PEMANFAATAN WARNA PADA POSTER BUKU CERITA BERGAMBAR SEJARAH PURA PULAKI." 


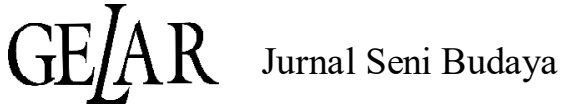

Desain 7(1): 71-84. https:// journal.Ippmunindra.ac.id/index.php/ Jurnal_Desain/article/view/3833.

Mikke, Susanto. 2011. Diksi Rupa. Yogyakarta: DictiArt.

Moleong, Lexy. 2000. Metode Penelitian Kualitatif. Bandung: Remaja Rosdakarya.

Novitasari, Dwi. 2018. "Kajian Estetika Melalui Bentuk Keseimbangan Ilustrasi Durga Dengan Teknik Sablon Discharge Sederhana." Bahasa Rupa 1(2): 73-80. https://jurnal.stikiindonesia.ac.id/index.php/jurnalbahasarupa/ article/view/263/80.

Nugraha, G Setya. 2013. Kamus Bahasa Indonesia Praktis. Surabaya: Sulita Jaya.

Nur, Susi Susyanti; Arif Budiman; Muhamad Hajid An. 2019. "Persepsi Visual Anak Muda Bandar Lampung Terhadap Motif Khas Lampung (Pucuk Rebung Dan Kapal)." Bahasa Rupa 3(1): 22-30. https://jurnal.stikiindonesia.ac.id/index.php/jurnalbahasarupa/ article/view/394/156.

Pendidikan, Jurusan, Seni Rupa, and Kesejahteraan Keluarga. 2013. "KAJIAN ESTETIKA RAGAM HIAS TENUN SONGKET." 2(1): 158-78.
Rianta, I Ketut Sariada; Hendra Santosa; I Made. 2019. "Estetika Gerak Tari Rejang Sakral Lanang Di Desa Mayong, Seririt, Buleleng, Bali." MUDRA Jurnal Seni Budaya 34(3): 385-93. https://jurnal.isi-dps.ac.id/index.php/mudra/ article/view/678.

Rohidi, Tjetjep Rohendi. 2011. Metodelogi Penelitian. Semarang: CV. Penerbit Cipta Prima Nusantara.

Sony, Kartika Dharsono. 2007. Estetika. Bandung: Rekayasa Sains.

Sugiyono. 2012. Metode Penelitian Kuantitatif, Kualitatif Dan Research \& Development. Bandung: Alfabeta.

Suhersono, Hery. 2011. Desain Bordir. Jakarta: PT. Gramedia Pustaka Utama.

Zaman, Chodijah \& Moh. Alim. 2011. Desain Mode Tingkat Dasar. Jakarta: Meutia Cipta Sarana.

\section{Narasumber:}

I Nyoman Sadra, BA, (68), Akupunturis (Kepala Desa Adat Tenganan Pegringsingan Tahun 19831993), Desa Adat Tenganan Pegringsingan

Ni Luh Widiartini, (45), Pengerajin Kain Tenun Gotya, Desa Adat Tenganan Pegringsingan. 